decreases in proportion as the appendicular region develops; further, in the former the palp and the intermaxilla dwindle as the galea (the sole directing portion) enlarges.

These facts seem to be of such a character as to modify the classic conception of the mandible ; further, they permit a rapid extension to other buccal organs. Such is the object of the researches on which I am at present engaged, and of which I hope to give the further results in a later communication.-Comptes Rendus, 1896, tom. cxxiii. pp. 608-610.

\title{
On the Hibernation of Clavelina lepadiformis, Müller.
}

By Mi. A. Giard and M. Caullery.

Clavelina lepadiformis, Müller, formerly somewhat rare on the coasts of the Pas de Calais, is become very abundant on the Bernard rocks, near Boulogne, since the establishment of the new port. To any one who observes the pretty corms of this Synascidian it is a very interesting problem to know how it is that the colonies, sometimes as large as the fist, disappear entirely in the winter, to reappear in the month of June in the following year, with the same development and in precisely the same positions. One cannot attribute the formation of these new corms to the proliferation of the oozoites produced by the old ones, because, rapid though the budding of these oozoïtes may be, it could not suffice to produce such large masses in so short a time. But if, towards the end of September or in October, or even during the equinoctial tides of the spring of the following year, one examines carefully the place occupied by the vanished colonies, there will be found adhering to the rocks numerous ramified and interlacing stolons, bearing here and there little whitish glomeruli of a chalky appearance, the whole constituting an ensemble which recalls well enough the general aspect of a colony of Bryozoons of the genus Bowerbankia. It is the form under which the Clavelina hibernates, reduced to tubular stolons filled at certain points with reserve material.

Nature of the Stolons. - The stolons in which the reserve material is accumulated are identical with those which during the summer unite amongst themselves the different individuals of the cormus, and on which are formed the ordinary blastozoites. They arise from the lower part of the abdomen of the individuals. Often they climb to the surface of these, and not infrequently the tunic of the stolon is so united as to be continuous with that of the individual. As, on the other hand, the stolons divide themselves into sections, one often sees isolated fragments of them crammed with reserve material, forming part at certain points with the tunic of individuals of which the branchia and digestive tube have more or less completely disappeared.

Like the normal stolons, the hibernating stolons enclose a prolongation of the epicardiac tube (" cloison stoloniale"), of which the two faces are fused.

Modifications of the Stolons.-At certain points more or less regularly interspaced the stolonial tube produces numerous lateral digitiform diverticula, forming the whitish glomeruli in which the reserves are accumulated, and which may be compared with the gemmules of sponges and the stutoblusts of the Bryozoa. On these 
glomeruli the exoderm of the stolon is rapidly modified. Instead of being very thin and flattened, it becomes cylindrical. The nuclei are usually on the internal face. The reserve material, in the form of white opaque granules, and staining with carmine, is arranged, on the contrary, on the external face. The reserve granules are essentially different from excreted pigments, white or yellow, which form the ornamental lines on different parts of the bodies of the Clavelince. In the lumen of the stolon there is found a mass of cellules which ought to be regarded as phagocytes, from the mesenchymatous elements arising without doubt from the mesoderm of the former animals of the colony. Many of these mesenchymatous cellules also enclose reserve material, always under the form of white granules, occupying in the protoplasm the vacuoles which are generally blended into one large central vacuole; the protoplasm and the nucleus are thrust out to the periphery. The cellules so modified can agglomerate, and they end by blocking up the greatly distended stolon. Although these cellules appear to multiply actively, we have never been able to observe mitosic figures. The epicardiac partition presents no modification; it is always very thin and the two leaves remain joined. After a certain time the stolons divide into sections completely isolated one from another; each new section presents numerous digitations. These various fragments always possess a portion of epicardium.

Further Evolution of the Sections.-The sections so isolated may remain for a longer or shorter time without evolution, according to the surrounding conditions. The development of the buds first shows itself by the change of aspect of the fragment of epicardium. The epicardial cells proliferate energetically by karyokinesis and become strongly colourable. They soon form a hollow vesicle, comparable to the internal vesicle of the normal buds of Synascidians; though we have not followed step by step the transformations of the vesicle, we do not doubt the homology of its ulterior development with that of the ordinary blastozoites of Clavelina. From the beginning of this process there is a rapid disappearance of the reserve material accumulated in the exoderm. The height of the epithelial cells diminishes in proportion as the cells multiply and empty themselves of their reserve material. The reserve material of the mesenchymatous cells disappears equally by digestion proper without the intervention of foreign elements.

Summary.-A. The reconstitution of the corms of Clavelina, after winter, is accomplished by a process of budding homologous with the normal process of budding.

$B$. The accumulation of reserres in the form described above is to be met with in the colonies collected in July. It is exaggerated in proportion as the sexual reproduction diminishes (August and September), and attains its maximum in autumn, when the old individuals of the cormus, first reduced to their tunic of cellulose, have finally disappeared.

$C$. It ought, then, to be interpreted as a normal physiological arrangement, permitting the latent life of the cormus during a certain time. It is a process of hibernation comparable with that which we have already described in the Polyclinidæ.-Comptes Rendus, 1896, tom. cxxiii. pp. 318-320. 


\section{$2 \mathrm{BHL}$ Biodiversity Heritage Library}

Giard, Alfred and Caullery, Maurice. 1896. "On the hibernation of Clavelina lepadiformis, Müller." The Annals and magazine of natural history; zoology, botany, and geology 18, 485-486. https://doi.org/10.1080/00222939608680499.

View This Item Online: https://www.biodiversitylibrary.org/item/63342

DOI: https://doi.org/10.1080/00222939608680499

Permalink: https://www.biodiversitylibrary.org/partpdf/58906

\section{Holding Institution}

University of Toronto - Gerstein Science Information Centre

\section{Sponsored by}

University of Toronto

\section{Copyright \& Reuse}

Copyright Status: NOT_IN_COPYRIGHT

This document was created from content at the Biodiversity Heritage Library, the world's largest open access digital library for biodiversity literature and archives. Visit BHL at https://www.biodiversitylibrary.org. 